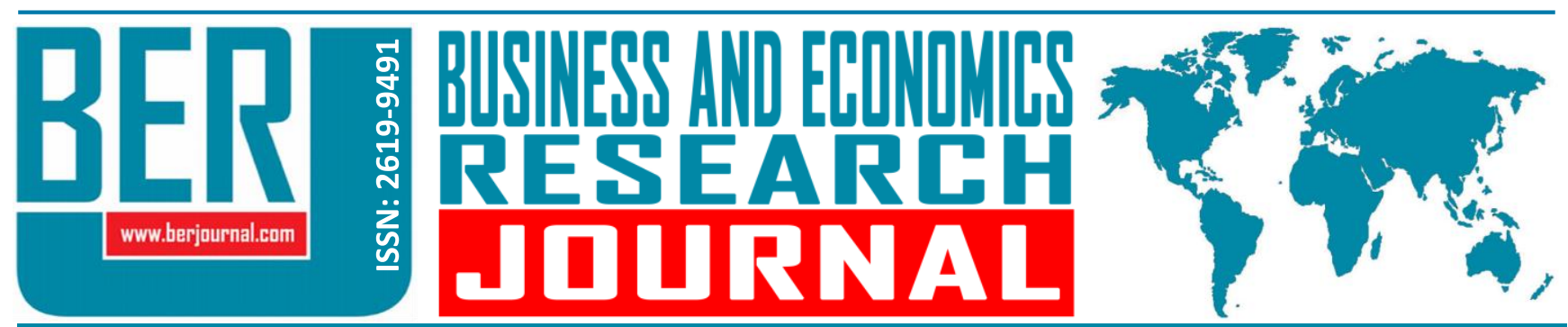

Business and Economics Research Journal Vol. 11, No. 2, 2020, pp. 555-570 doi: 10.20409/berj.2020.267

\section{Teknostresin Presenteizm ve İşten Ayrılma Niyetine Etkisinde Dönüşümcü Liderliğin Aracı Rolü}

\author{
Berat Cicek $^{\mathrm{a}}$, Erman Kilinc $^{\mathrm{b}}$
}

Öz: Bu çalışmanın temel amacı, teknostresin örgütlerdeki presenteizm ve işten ayrılma niyetine etkisinde dönüşümcü liderliğin aracı rolünü tespit etmektir. Araştırma kapsamında veri toplama araçları olarak anket formları kullanılmıştır. Alan araştırması için Malatya ili seçilmiş ve bu ilde görev yapan Türkiye Cumhuriyeti Devlet Demiryolları (TCDD) çalışanlarına anket formları dağıtılmıştır. Uygulama aşamasında verilere öncelikle güvenilirlik, normallik ve faktör analizleri yapılmıs ardından ise yapısal eşitlik modeli kurulmuştur. Araştırma sonucunda teknostresin tekno - aşırı yük, tekno karmaşıklık ve tekno - iş güvencesizliği boyutları için presenteizm davranışını etkilediği; teknostresin tekno - karmaşıklık, tekno - iş güvencesizliği ve tekno - belirsizlik boyutları için dönüşümcü liderlik algısını etkilediği; dönüşümcü liderliğin presentezim davranışını ve işten ayrılma niyetini etkilediği ve dönüşümcü liderliğin teknostres ile presenteizm arasındaki ilişkide aracı rol oynadığı bulunmuştur. Elde edilen sonuçların örgütlerde sıklıkla görülen teknostresin etkilerini azaltmaya ve presenteizm ile işten ayrılma niyetlerinin örgütlerde yayılmasının önüne geçmeye katkı sağlayacağı düşünülmektedir.

\section{The Mediating Role of Transformational Leadership in the Effect of Technostress on Presenteeism and Intention to Leave}

\begin{abstract}
The main purpose of this study is to determine the mediating role of transformational leadership in the effect of technostress on presenteeism and intention to quit in organizations. Survey forms were used as data collection tool. Malatya province was chosen for the field study and survey forms were distributed to employees who work in the Turkish State Railways. In the application phase, firstly reliability, normality and factor analysis were performed and then the structural equation model was established. As a result of the research, technostress influenced presenteeism behavior for techno - overload, techno - complexity and techno - job insecurity dimensions; technostress affects the perception of transformational leadership for techno - complexity, techno - job insecurity and techno - uncertainty dimensions, transformational leadership affects presenteeism behavior and intention to quit, and transformational leadership plays a mediating role in the relationship between technostress and presenteeism. It is thought that the results obtained will contribute to reducing the effects of technostress which is frequently seen in organizations and preventing the spread of presenteeism and intention to quit in organizations.
\end{abstract}

Anahtar Sözcükler: Teknostres, Presenteizm, İșten Ayrılma Niyeti, Dönüşümcü Liderlik

JEL: M10, M12, C12

$\begin{array}{ll}\text { Geliş } & : 06 \text { Ocak } 2020 \\ \text { Düzeltme } & : 07 \text { Şubat } 2020 \\ \text { Kabul } & : 04 \text { Mart 2020 } \\ \text { Tür } & \text { : Araştırma }\end{array}$

Keywords: Technostress, Presenteeism, Intention to Quit, Transformational Leadership

JEL: M10, M12, C12
Revised : 07 February 2020

Accepted : 04 March 2020

Type : Research

a Asst. Prof., PhD., Mus Alparslan University, Faculty of Economics and Administrative Sciences, Mus, Turkiye, b.cicek@alparaslan.edu.tr (ORCID ID: 0000-0002-4584-5862)

b Asst. Prof., PhD., Nigde Omer Halisdemir University, Ulukisla Vocational School, Nigde, Turkiye, ermankilinc@ohu.edu.tr (ORCID ID: 0000-0001-7065-5916) 


\section{Giriş}

İçinde bulunduğumuz bilgi toplumunda oldukça hızlı şekilde gerçekleşen teknolojik yenilikler müşteri taleplerini ve örgütler arası rekabeti artırmıştır. Bu durum, örgütlerin çalışanlardan teknolojiye ayak uydurmalarını, kendilerini sürekli geliştirmelerini ve daha fazla görev yerine getirmelerini beklemesine yol açmıştır. Artan örgütsel beklentiler beraberinde örgütsel stresi getirmiştir (Laspinas, 2015). Teknolojinin örgüt içinde kullanımının artmasına ve dolayısıyla artan iş yüküne bağlı olarak oluşan stres, çalışanları olumsuz yönde etkilemekte hatta bu durum bazen yıkıcı etkilere neden olmaktadır. Söz konusu yıkıcı etkiler; hafıza kaybı, dikkat eksikliği, depresyon, öfke, uyku bozukluğu gibi psikolojik veya kas, eklem, baş ağrısı ve mide bulantısı gibi fiziksel özellikte olabilmektedir. Tüm bu etkilere ve daha fazlasına neden olan ve devam etmesi halinde örgütlere büyük sıkıntı yaşatan kavrama "teknoloji kaynaklı kaygı" (technology - induced anxiety) ya da kısaca "teknostres" adı verilmektedir (Tarafdar, Ragu-Nathan, Ragu-Nathan ve Tu, 2007).

Hemen her yaşta görülebilen teknostres, bazen yapılan rutin işlerde bazen de çalışanların teknolojik yeniliklere uyum sağlayamadığı durumlarda ortaya çıkmaktadır. Çalışanların teknolojik yeteneklerini ve yeterliliklerini sürekli geliştirmesi teknostresin azalmasına neden olmaktadır (Laspinas, 2015). Teknostres kavramı ilk olarak 1984 yılında Craig Brod tarafından kullanılmış ve "yeni teknolojilere uyumsuzluk sonucu ortaya çıkan adaptasyon hastalı̆̆ı" olarak ifade edilmiştir. Champion'a (1988) göre ise teknostres, "değişen teknolojiye karşı bireysel tepkidir" (Çetin ve Bülbül, 2017). Teknostresi, "teknoloji kaynaklı psikolojik ve fizyolojik olumsuz etkiler" olarak tanımlamak mümkündür.

Teknostresin çalışanlar aracılığıyla örgütlere de olumsuz etkileri vardır. Bu etkiler arasında; sinirlilik, hata oranlarının ve devamsızlıkların artması, moral düşüklüğü, tükenmişlik, odaklanma problemleri (Çetin, 2017), örgütsel bağlılıkta ve iş tatminde azalma ile iş gücü devrinde artış yer almaktadır (Ayyagari, Varun ve Russell, 2011). Örgütlerin işlerini büyük ölçüde kolaylaştıran ve kârlılıklarını artıran teknolojinin beraberinde gelen problemin çözülmesi örgütler için hayati önem taşımaktadır. Zira Amerikan Stres Enstitüsü (2007), örgütlerde yaşanan stresin örgütlere maliyetini 300 miyar dolar olarak hesaplamıştır.

Teknostresin örgütlerdeki olumsuz etkilerinden birisi işten ayrılma niyetidir (Tu, Wang ve Shu, 2005). İsten ayrılma durumunda sadece çalışan örgütten ayrılmakla kalmamakta aynı zamanda edindiği bilgi ve tecrübeleri de beraberinde götürmektedir. Bu durum ise örgütlere yeniden çalışan seçme ve yerleştirme, eğitim, denetim ve adaptasyon maliyetlerini beraberinde getirmektedir (Sanderson, 2003). Teknostresin örgüterdeki diğer etkisi ise presenteizmdir (işte sözde var olma) (Ayyagari vd., 2011). Presenteizm, çalışanların ciddi sağlık problemlerine rağmen işe gitmeye devam etmeleri demektir. Bu durumdaki çalışanlar fiziksel olarak işe gitseler bile verimsiz bir şekilde görev yapmaktadır. Presenteizmin neden olduğu verimlilik kaybı tam olarak hesaplanamasa da absenteizme (işe devamsılık) göre daha yüksek olduğu belirlenmiştir (Cullen ve McLaughlin, 2006).

Örgütlerin karşılaştığı yeni çevresel koşullara uyum sağlama ve problemlere kalıcı çözümler üretmede liderlere önemli görevler düşmektedir. Çevreye uyum ve örgüte yeni yön vermede en etkili liderlik türlerinden biri dönüşümcü liderliktir. Teknostresin anksiyete, teknofobi, korku ve endişeye yol açarak örgütsel değişime direnç halini almaması için dönüşümcü lider tarafından acil tedbirlerin alınması önemlidir.

Bu çalışmada, teknostresin presenteizm ve işten ayrılma niyetine etkisinde dönüşümcü liderliğin aracı rolünün ortaya konulması amaçlanmıştır. Bu amaç doğrultusunda nicel bir araştırma gerçekleştirilmiştir. Elde edilen veriler yapısal eşitlik modellemesi yaklaşımına göre analiz edilmiştir. Gerçekleştirilen yazın taramasında söz konusu dört bileşenin olduğu bir çalışmaya rastlanmamıştır. Araştırmanın bu yönüyle özgün olduğu düşünülmekte ve ilgili yazına katkı sunması beklenmektedir.

\section{Kavramsal Çerçeve}

\subsection{Teknostres}

Günümüzde giderek zorlaşan rekabet koşulları bilgi ve iletişimin yoğun olarak kullanılmasını gerektirmektedir. Bu durumda çalışanların, sürekli olarak gelişen ve giderek daha karmaşık hale gelen teknolojiye uyum sağlamak amacıyla teknoloijk yetenek ve yeterliliklerini geliştirmesi gerekmektedir 
(Laspinas, 2015). Teknolojinin karmaşık yapısına artan çoklu görevler de eklenince bu durum çalışanlarda endişe ve korkuya sebep olmaktadır (Clark ve Kalin, 1996). Bu stres kaynağının adı ise teknostrestir. Teknostres, "yeni teknolojilere uyum sağlayamamaktan doğan modern bir uyum hastalığı" olarak tanımlanmaktadır (Akınoğlu, 1993).

Tarafdar vd. (2007) teknostresin beş boyutu olduğunu öne sürmüştür:

- Tekno - Aşırı Yükleme: Bilgi ve iletişim teknolojileri kullanıcılarından daha hızlı ve uzun süreli çalışmalarının beklenmesidir.

- Tekno - İstila: Bilgi ve iletişim teknolojileri kullanıcılarından sürekli ulaşılabilir olmalarının beklenmesidir.

- Tekno - Karmaşıkık: Bilgi ve iletişim teknolojileri kullanıılarından giderek daha karmaşık yapıya bürünen teknoloji araçlarına uyum sağlamalarının beklenmesi ve bu durumun daha fazla çalışmayı gerektirmesidir.

- Tekno - Güvensizlik: Bilgi ve iletişim teknolojilerini kullanması gereken çalışanların teknolojideki sürekli değişime uyum sağlayamama sonucunda işini kaybetme korkusu yaşamasıdır.

- Tekno - Belirsizlik: Bilgi ve iletişim teknolojilerini kullanması gereken çalışanların teknolojik değişimin sürekli olması neticesinde kendi durumlarını belirsiz olarak görmesidir.

Son kullanıcıya yönelik bilgi işlem ve ağ teknolojilerindeki hızlı büyüme, teknolojinin ciddiyetini de artırmıştır (Brillhart, 2004). Bu ciddiyet beraberinde teknoloji bağımlılığı veya teknolojiye karşı stres gibi mental rahatsızlıkları da beraberinde getirmiştir (Lee, Chang, Lin ve Cheng 2014). Literatürde teknostresin çalışanlara yönelik oldukça önemli etkileri olabileceği sıkça tartışılmaktadır. Bu etkiler; işe yabancılaşma (Hung, Chang ve Lin, 2011), öfke (Brillant, 2004), iş memnuniyetsizliği, bilgisayar fobisi (Ragu-Nathan, Tarafdar, Ragu-Nathan ve Tu, 2008), görevlere katılımdan kaçınma, düşük performans, düşük verimlilik (Tarafdar vd., 2007) ve sağlık sorunları (Riedl, Kindermann, Auinger ve Javor, 2012) olabilmektedir.

\subsection{Presenteizm}

Örgütlerde sıklıkla karşılaşılan problemlerden biri çalışanın işte olmasına rağmen kendini işe verememesi ve bunun sonucunda düşük verimde çalışmasıdır (Ferreira ve Martinez, 2012). Özellikle 20. yy’ın ortalarından itibaren araştırılan ve "iş yerinde sözde var olma" şeklinde tanımlanan problemin adı presenteizmdir. Presenteizm ifadesi, ilk olarak Mark Twain'in 1892 yılındaki "The American Claimant" adlı kitabında kullanılmıştır. Uzun yıllar farklı anlamlarda kullanılan presenteizmin tanımını örgütsel yönetim uzmanı Cooper ve Williams (1994) şu şekilde yapmıştır: Presenteizm, mutsuz, üzgün veya rahatsız olduğu halde işini kaybetme korkusuyla işine devam eden; fakat işe katkısı oldukça sınırlı olan çalışanın durumudur. Bayar'a (2016) göre presenteizm, çalışanın kendini iyi hissetmemesine rağmen evde dinlenmeyi reddederek işe gitmek zorunda kalması ve rahatsız olduğu için kendini işe veremeyerek verimsizliğe neden olmasıdır.

Çiçek ve Aknar (2019: 1238) presenteizmi, "işletmenin içinde bulunduğu durumun oluşturduğu baskı sonucunda işini kaybetme, terfi edememe korkusu vb. nedenlerle çalışanın hasta olmasına rağmen işyerine gitmesi, fazla çalışma koşullarından dolayı yakınması ve mesai saatleri içerisinde görevi içerisinde olmayan işleri yaparak performansının düşmesi, buna bağlı olarak da üretkenliğinin-verimliliğinin düşmesi ve bedenen bulunduğu ortamda zihnen olmaması" olarak tanımlamıştır. Kavram bazı araştırmacılar tarafından "örgütlerdeki hasta işgörenler" şeklinde tanımlanmıştır (D’Abate ve Eddy, 2007). Söz konusu çalışanlar örgütler açısından ölçülmesi zor ve karmaşık olan verimlilik kayıplarına neden olmaktadır (Isetti ve Meyer, 2014). Esasen, fiziksel veya psikolojik problemlerine rağmen işine düzenli olarak giden ve sanki iş yapıyormuş gibi görünen çalışanlar aynı zamanda daha verimli olanların yerlerine geçmesine engel olmaktadır (İş̧an ve Moç, 2018).

Presenteizmin başlıca nedenleri arasında örgütsel zayıflıklar, olumsuz lider davranışları, örgüt içindeki belirsizlikler ve örgütün sağlığına zarar verebilecek her türlü etken yer almaktadır (Lowe, 2004). Çiftçi'ye (2010) göre presenteizm sorununu çözmek için; örgüt kültürünü yeniden şekillendirmek, işleri yeniden 
tasarlamak ve yeni çalışma usulleri denemek, örgütsel sağlığa önem vererek stresle başa çıkma yöntemlerini uygulamak ve iş - yaşam dengesinin kurulabilmesi amacıyla çalışan destek programları düzenlemek gerekmektedir. Presenteizm; bilişsel, duyuşsal ve davranışsal olmak üzere üç boyuttan oluşmaktadır.

Presenteizmin sonuçları incelendiğinde; Saarvala (2006) presenteizmin, Kanada'daki işletmelere yılda ortalama 15-25 milyar ABD Doları arasında bir gidere mâl olduğunu belirtmiştir. Hemp (2004), 2000 yılında ABD'nin sağlık harcamalarının \%63'ü (311,8 milyon ABD Doları) gibi büyük bir oranın presenteeizmden kaynaklandığını belirtmiştir. Samuel ve Wilson (2007) ise ABD ekonomisindeki presenteizmden kaynaklanan verimlilik kaybının yaklaşık 180 milyar ABD Doları olduğunu belirtmişlerdir.

Ayyagari vd. (2011) 661 bilgi ve iletişim teknolojileri çalışanları üzerinde gerçekleştirdikleri araştırıma sonucunda teknostresin presenteizm ile ilişkisi olduğunu tespit etmiştir. Knani (2013) ile Issa ve Bahli (2018) güncel teknolojik gelişmelere ayak uyduramamanın işletmelerde presenteizm davranışına neden olabileceğini savunmuştur. Buradan hareketle araştırmada test edilmek üzere aşağıdaki hipotez kurulmuştur:

$\mathbf{H}_{1}$ : Teknostres presenteizm davranışını etkilemektedir

\section{3. İșten Ayrılma Niyeti}

İşten ayrılma niyeti, dünya genelinde irili ufaklı tüm örgütlerde yaşanan ortak bir sorundur. İşten ayrııma niyeti, çalışanın görev yaptığı örgütten ayrılma konusunda bilinçli olarak karar vermesi, buna niyet etmesi (Bartlett, 1999) ya da çalışanın belirli bir süre görev yaptıktan sonra örgütünden gönüllü veya gönülsüz olarak ayrılmasıdır. Gönüllü işten ayrılma, çalışanın daha iyi olanı tercih etme veya daha fazla çalışma gücünü kendinde bulamama gibi nedenlerden; gönülsüz işten ayrılma ise çalışanın emeklilik, ölüm, zorunlu kişisel sebepler ya da işten çıkarılma gibi nedenlerden kaynaklanmaktadır (Bayarçelik ve Fındıklı, 2017). Kaya'ya (2010) göre ise işten ayrılma niyetini oluşturan etmenler üçe ayrılmaktadır:

- Genel Ekonomik Nedenler: Ülkenin içinde bulunduğu ekonomik şartlar, refah düzeyindeki artış, başka örgütlerde iş bulmanın kolaylaşması gibi ekonomik nedenler.

- Örgüt İçi Nedenler: Örgütün konumu, görevin zorluk derecesi, ücretlendirme politikaları, çalışma ortamı, kötü yönetim tarzları gibi örgütsel nedenler.

- Kişisel Yaşam Şartlarına Bağıı Nedenler: Ailevi nedenler, çalışanın başka mesleklere ilgi duyması, sağlık problemleri, yaşlılık, eğitim görme isteği ve diğer psikolojik veya fiziksel nedenler.

İşten ayrılma niyeti, örgütler açısından ciddi maddi kayıplara neden olmaktadır. Söz konusu kayıplar daha çok işe son verme, yeni iş ilanına çıkma, işe alma süreçlerinde ve sonrasında yapılması gereken denetim ve adaptasyon faaliyetlerinde ortaya çıkmaktadır. Örgütler bahsi geçen kayıpları ortadan kaldırmak veya en aza indirmek için çaba sarf etmektedir (Khan, Nawaz, Khan, Khan ve Yar, 2013). Özellikle, işten ayrılan çalışan kritik öneme sahipse ve çalışanın yeri ikame edilemiyorsa bu durum örgütler açısından daha büyük problemlere yol açabilmektedir.

Literatürde işten ayrılma niyeti ile ilgili pek çok araştırma mevcuttur. Bu araştırmalara göre iş tatmini ve işten ayrılma niyeti arasında önemli bir ilişki söz konusudur (Hang-Yue, Foley ve Loi, 2005). Ek olarak, yüksek seviyede strese sahip çalışanların iş tatmini seviyeleri düşüktür ve iş stresine neden olan etmenler çalışanların becerilerini olumsuz yönde etkilemektedir (Tekingündüz, Top ve Seçkin, 2015). 25 yıllık süre zarfındaki çalışmaları kapsayan bir meta-analize dayanarak, Fried, Shirom, Gilboa ve Cooper (2013) rol stresi ile işten ayrılma niyeti arasında orta dereceli bir ilişki olduğu sonucuna varmıştır. Tu vd. (2005) ise Çin'de görev yapan IT çalışanları üzerinde gerçekleştirdikleri araştırma sonucunda teknostresin tükenmişlik, iş tatminsizliği ve işten ayrılma niyetine etki ettiğini tespit etmiştir. Buna göre araştırmanın ikinci hipotezi şu şekilde kurulmuştur:

$\mathbf{H}_{2}$ : Teknostres işten ayrılma niyetini etkilemektedir 


\subsection{Dönüşümcü Liderlik}

1980 'li yıllardan itibaren giderek hız kazanan rekabet ve değişim hızına ayak uydurma ihtiyacı yeni bir liderlik türünün doğmasına neden olmuştur. İlk olarak James Victor Dawston tarafından 1973 yılında yazılan "isyan Liderliği" isimli kitapta adı geçen liderlik türü dönüşümcü liderliktir. Bass (1997) dönüşümcü liderliği, çalışanlar üzerinde yüksek seviyede moral ve motivasayon sağlayarak performans elde eden lider; Gül (2003) ise çalışanları sürekli daha iyisini yapma konusunda motive eden, büyük hedefler ortaya koyarak onları bu hedefler etrafında birleştiren ve örgütsel değişimi gerçekleştiren lider olarak tanımlamıştır.

Dönüşümcü liderin bazı karakteristik özellikleri vardır. Bunların başlıcaları; çalışanlar üzerinde güçlü etkiye sahip olma, yaratıcılığa ve yenilikçiliğe önem verme, örgütsel reformun temsilcisi olma, değişimi yönetme, risk alma ve tutarlı olmadır (Kılınç, 2019).

Dönüşümcü liderlik dört boyuttan oluşmaktadır (Bass, 1997):

- Karizma: Liderin çalışanların ihtiyaçlarını kendi ihtiyaçlarının üzerinde tutarak, riskleri paylaşarak ve çalışanlarının değerlerine uyum sağlayarak onları etkilemesidir.

- IIham Verici Motivasyon: Liderin ortak vizyon oluşturarak, oluşturulan vizyonu çalışanlara ileterek ve onların gayretlerine semboller aracılığıyla yoğunlaşarak izleyenlerine model olmasıdır.

- Entelektüel Etki: Liderin çalışanların problemlerinin bilincinde olması, söz konusu problemlere farklı açılardan bakarak çözüm üretmesi ve bu sayede çalışanları etkilemesidir.

- Bireyselleştirilmiş ilgi: Liderin her bir çalışanı tek başına ele alarak onun ihtiyaçlarını tespit etmesi, ona yardımcı olması ve kendisini geliştirmesini sağlamasıdır.

Boyer-Davis (2018) Amerika'da görev yapan 129 bilgi teknolojleri müdürü üzerinde gerçekleştirdiği araştırma sonucunda dönüşümcü liderliğin teknostres ile ilişkisi olduğunu tespit edememiş; fakat dönüştürücü ve tam serbesti tanıyan liderliğin teknostres ile ilişkisi olduğunu tespit etmiştir. Ayrıca, Fieseler, Grubenmann, Meckel ve Müller (2014) ve Boyer-Davis (2019) çalışmalarında teknostresin etkilerini azaltabilecek liderlik tipleri içerisinde dönüşümcü liderliği göstermiştir. Buna göre araştırmanın üçüncü hipotezi şu şekilde kurulmuştur:

$\mathbf{H}_{3}$ : Teknostres dönüşümcü liderlik algısını etkilemektedir.

Larjovuori, Bordi, Mäkiniemi ve Heikkilä-Tammi (2016) çalışmalarında, dijitalleşme sürecinde dönüşümcü liderin önemli bir role sahip olabileceğini ve sancılı geçecek bu sürece dönüşümcü liderin takipçilerini hazırlayabilecek potansiyele sahip olduğunu belirtmişlerdir. Nielsen ve Daniels (2016) ise dönüşümcü liderlik ile takipçilerin presenteizm davranışı arasında negatif yönlü bir ilişki olduğunu tespit etmişlerdir. George, Chiba ve Scheepers'ın (2017) araştırma bulguları dönüşümcü liderliğin stres kaynaklı presenteizme etki ettiğini göstermiştir. Ayrıca, Ariyabuddhiphongs ve Kahn (2017) dönüşümcü liderin çalışanları işten ayrılma niyetinden geri döndürebileceğini ortaya koymuştur. Tüm bu ilişkilerden hareketle dönüşümcü liderin teknostres ile presenteizm ve işten ayrılma niyeti arasındaki ilişkiye aracılık edebileceği düşünülmüştür. Buradan hareketle araştırma test edilmek üzere aşağıdaki hipotezler oluşturulmuştur.

$\mathbf{H}_{4}$ : Dönüşümcü liderlik presenteizm davranışını etkilemektedir

$\mathbf{H}_{5}$ : Dönüşümcü liderlik işten ayrılma niyetini etkilemektedir

$\mathbf{H}_{6}$ : Dönüşümcü liderlik teknostres ile presenteizm davranışı arasındaki ilişkide aracı etkiye sahiptir

$\mathbf{H}_{7}$ : Dönüşümcü liderlik teknostres ile işten ayrılma niyeti arasındaki ilişkide aracı etkiye sahiptir

\section{Yöntem}

Bu çalışmada demiryolu çalışanlarının teknostres algılarının, onların işten ayrılma niyetlerine ve presenteizm davranışlarına etkisi ve bu değişkenler arasındaki ilişkide dönüşümcü liderlik tarzının aracı rolünün irdelenmesi amaçlanmıştır. Bu amaç doğrultusunda nicel bir araştırma yapılmıştır. Bu bağlamda TCDD’nin Malatya'daki çalışanları ve yöneticileri ile bir anket çalışması gerçekleştirilmiştir. Elde edilen veriler 
yapısal eşitlik modellemesi (YEM) yaklaşımına göre analiz edilmiştir. YEM, sosyal bilimler ve davranış bilimleri içindeki teorik modelleri açıklamada yaygın olarak kullanılan bir yöntemdir (Quintana ve Maxwell, 1999; Martens, 2005; Weston ve Gore, 2006). Iacobucci, Saldanha ve Deng (2007) YEM'in teorik ve ampirik çalışmaların istatistiki olarak daha gelişmiş bir zeminde yapılmasını sağladığını belirtmiştir. Bu nedenlerle verilerin analizinde YEM yaklaşımı tercih edilmiştir. Araştırmada test edilmek üzere kurulan model Şekil 1'de verilmiştir.

Şekil 1. Araştırmanın Modeli

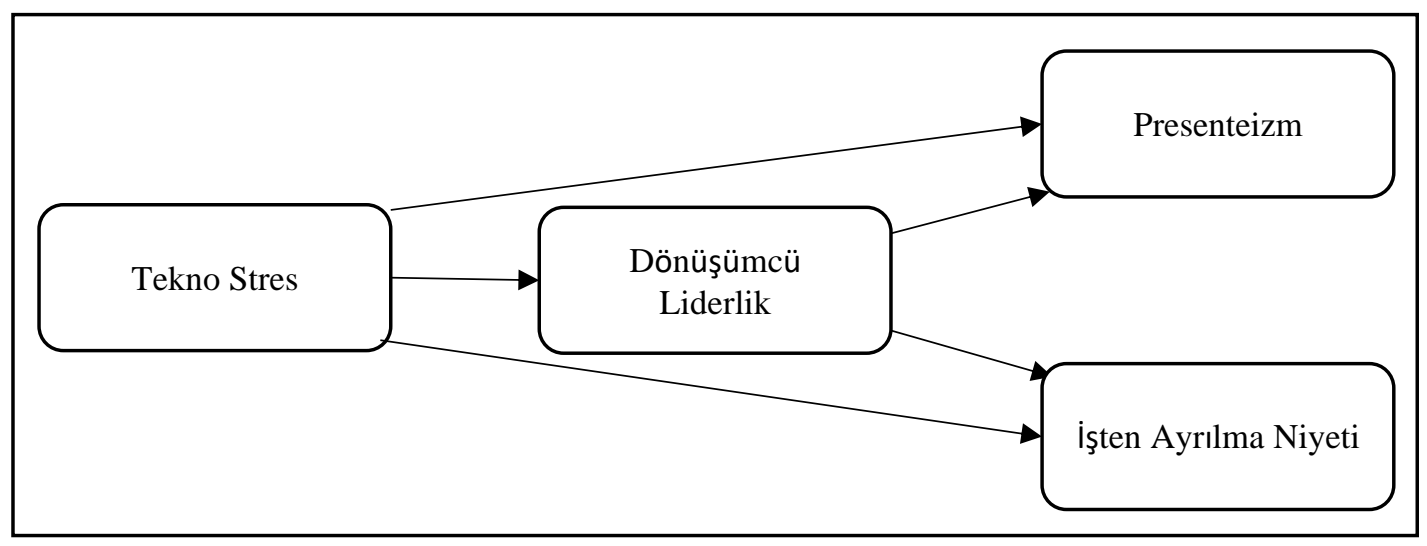

Çalışmada kurulan modeli ve hipotezleri test edilmek için Anderson ve Gerbing'in (1988) iki aşamalı yaklaşımı takip edilmiştir. Öncelikle yaklaşımın ilk adımı olan ölçüm modeli kurulmuştur ve değişkenlerin uyuşum ve ayırt edici geçerliliği sağlayıp sağlamadığını ortaya koymak için Mplus 8.4 (Muthén ve Muthén, 2017) programı ile doğrulayıcı faktör analizi (DFA) yapılmıştır. Değişkenler için ayırt edici ve uyuşum geçerliliği sağlandıktan sonra, önerilen modeli test etmek için yapısal eşitlik modellemesi yapılmıştır. Aracılık modelini test etmek için ( 5000 yinelemeli) bootstrapping yöntemi kullanılmıştır. Williams ve MacKinnon'a (2008) göre aracılık testi için en güçlü dolaylı etki testi bootstrapping yöntemidir. Bu nedenle aracı rol analizinde bu yöntem tercih edilmiştir.

\section{1. Ölçüm Araçları}

Araştırmada kullanılan anket formu beş bölümden oluşmaktadır. illk bölümde katılımcıların demografik bilgilerini (cinsiyet, medeni hâl, yaş, eğitim düzeyi, görev, mevcut iş yerindeki çalışma süresi ve mevcut amirle çalışma süresi) içeren sorular; ikinci bölümde Bass ve Avolio (1994) tarafından geliştirilen ve Türkçeye Attar (2014) tarafından çevrilen 4 boyut - 20 ifadeli dönüşümcü liderlik ölçeği; üçüncü bölümde tarafından Tarafdar vd. (2007) tarafından geliştirilen ve Türkçeye Ilgaz, Özgür ve Çuhadar (2016) tarafından çevrilen 5 boyut - 23 ifadeli teknostres ölçeği; dördüncü bölümde Cammann, Fichman, Jenkins ve Klesh (1983) tarafından geliştirilen tek boyut - 3 ifadeli işten ayrılma niyeti ölçeği ve beşinci bölümde Koopman vd. (2002) tarafından geliştirilen ve Türkçeye Coşkun (2012) tarafından çevrilen tek boyut - 6 ifadeli presenteizm ölçeği yer almaktadır. Anket formunda yer alan ölçeklerin tamamı 5'li Likert tipinde hazırlanmıştır. Ölçek aralıkları "1- Hiç Katılmıyorum; 5- Tamamen Katılıyorum" şeklinde kodlanmıştır.

Tüm çalışan ve yöneticilerden aynı anda veri toplandığı için ortak yöntem varyansı problem yaratabilmektedir. Ortak yöntem varyansı, yapıların kendisinden ziyade paylaşılan ölçüm yöntemlerine dayandırılabilecek varyansa atıfta bulunmakta ve bu durum ölçüm hatalarına neden olabilmektedir (Podsakoff, MacKenzie, Lee ve Podsakoff, 2003). Ortak yöntem varyansını test etmek için Harman'ın (1967) "single - factor (tek - faktör)" testi uygulanmıştır. Buna göre döndürme yöntemi uygulamadan tüm maddeler tek faktör altında incelenmiştir. Oluşturulan bu faktör tarafından açıklanan varyans miktarı \%38'dir. Bu değer \%50’nin altında olduğu için ortak yöntem hatası olmadığı tespit edilmiştir (Kline, 2005). 


\subsection{Katılımcılar}

Araştırmaya veri toplamak için TCDD'nin Malatya operasyonlarında görevli çalışanlarla bir anket gerçekleştirilmiştir. Anketler çalışanlarla yüz yüze gerçekleştirilmiştir. Anketlere başlanmadan önce katılımcılara, cevapların gizli kalacağı, sadece akademik amaçlarla kullanılacağı ve çalışmanın gönüllülüğe dayandığına dair bilgiler deklare edilmiştir. Bu bağlamda çalışmaya katılmaya gönüllü olan çalışanlara ilişkin demografik bilgiler Tablo 1'de verilmiştir.

Tablo 1. Katılımcıların Demografik Bilgileri

\begin{tabular}{|c|c|c|c|c|c|c|c|}
\hline & & Sayı & Yüzde & & & Sayı & Yüzde \\
\hline \multirow{2}{*}{ Cinsiyet } & Kadın & 51 & 21,4 & \multirow{2}{*}{ Medeni Durum } & Evli & 184 & 77,3 \\
\hline & Erkek & 187 & 78,6 & & Bekar & 54 & 22,7 \\
\hline \multirow{4}{*}{ Yaş } & $18-30$ arası & 57 & 23,9 & \multirow{4}{*}{ Eğitim Durumu } & ilkokul & 4 & 1,7 \\
\hline & 31-43 arası & 89 & 37,4 & & Ortaokul & 11 & 4,6 \\
\hline & $44-56$ arası & 76 & 31,9 & & Lise & 57 & 23,9 \\
\hline & 57 ve üzeri & 16 & 6,7 & & Yüksek Öğrenim & 166 & 69,7 \\
\hline \multirow{8}{*}{ Kadro } & İşçi & 12 & 5,0 & \multirow{4}{*}{$\begin{array}{l}\text { Mevcut İşyerinde } \\
\text { Çalışma Süresi }\end{array}$} & $0-8 \mathrm{yıl}$ & 118 & 49,6 \\
\hline & Memur & 160 & 67,2 & & 9-17 yıl & 47 & 19,7 \\
\hline & Yönetici & 21 & 8,8 & & $18-26$ yıl & 31 & 13,0 \\
\hline & Taşeron & 19 & 8,0 & & 27 yıl ve üzeri & 42 & 17,6 \\
\hline & Stajyer & 22 & 9,2 & \multirow{4}{*}{$\begin{array}{l}\text { Mevcut Amirle } \\
\text { Çalışma Süresi }\end{array}$} & $0-8 \mathrm{yll}$ & 183 & 76,9 \\
\hline & Diğer & 4 & 1,7 & & 9-17 yıl & 31 & 13,0 \\
\hline & & & & & $18-26$ yıl & 13 & 5,5 \\
\hline & & & & & 27 yıl ve üzeri & 11 & 4,6 \\
\hline
\end{tabular}

Ankete başlangıçta 246 kişi katılmıştır. Yapılan testlerde anketlerden sekizi aykırı değer oluşturduğu için değerlendirmeye alınmamıştır. Değerlendirmeye alınan anketlere göre katılımcıların 51'i kadın 187'si ise erkektir. Katılımcılar çoğunlukla 31-43 yaş aralığında iken, en fazla memurlar ankete katılım göstermiştir. Eğitim durumu açısından incelendiğinde en fazla yükseköğrenim mezunu olduğu görülmüştür. Ayrıca gerek mevcut işyerinde çalışma süresi açısından gerekse de mevcut amirle çalışma açısından en fazla yoğunluğun 0-8 yıl arasında olduğu tespit edilmiştir.

\section{3. Ölçüm Modeli}

Ölçeklerin yapı geçerliliğini ve güvenirliğini test etmek için faktör analizi yapılmıştır. Faktör analizindeki iki ana yaklaşım açımlayıcı ve doğrulayıcı faktör analizi yaklaşımlarıdır (Kahn, 2006). Açımlayıcı faktör analizi (AFA) bir belirleme işlevini hipotez kurmaya yönelik bilgi edinilmesini sağlamaya çalışırken, doğrulayıcı faktör analizi (DFA), belirlenen bu faktörler arasında yeterli düzeyde ilişkinin olup olmadığını, hangi değişkenlerin hangi faktörlerle ilişkili olduğunu, faktörlerin birbirlerinden bağımsız olup olmadığını, faktörlerin modeli açıklamakta yeterli olup olmadığını sınamak için kullanılmaktadır (Erkorkmaz, Etikan, Demir, Özdamar ve Sanisoğlu, 2013).

DFA'da analizin planlanması gözlemlenen ve gözlemlenmeyen değişkenler arasındaki teorik ilişkiler tarafından yönlendirilmektedir. Başka bir deyişle bir DFA yapıldığında, araştırmacı gözlemlenen kovaryans matrisi ile karşılaştırılan bir popülasyon kovaryans matrisini tahmin etmek için varsayımsal bir model kullanmaktadır. Kovaryans temelli YEM de bir nevi doğrulama temelli bir teknik olduğundan YEM yapılırken DFA kullanılması oldukça yaygın bir yaklaşımdır (Schreiber, Nora, Stage, Barlow ve King, 2006).

Araştırmada kullanılan ölçeklere öncelikle AFA yapılmıştır. AFA sonuçlarına göre teknostres, dönüşümcü liderlik ve işten ayrılma niyetlerinin orijinal ölçek yapılarını koruduğu görülmüştür. Presenteizm ölçeğinin ise orijinal halinin aksine iki boyutlu bir yapıya büründüğü gözlemlenmiştir. Daha sonra oluşan bu yeni yapıyı test etmek üzere DFA yapılmıştır. Yapılan DFA sonucunda elde edilen uyum indeksleri Tablo 2 'de verilmiştir. 
Tablo 2. Ölçeklerin DFA Uyum İndeksleri

\begin{tabular}{|c|c|c|c|c|c|c|c|}
\hline & $\begin{array}{c}\chi^{2} / d f \\
<5\end{array}$ & $\begin{array}{l}\text { AGFI } \\
>0,85\end{array}$ & $\begin{array}{c}\text { GFI } \\
>0,80\end{array}$ & $\begin{array}{c}\text { CFI } \\
>0,90\end{array}$ & $\begin{array}{c}\text { NFI } \\
>0,90\end{array}$ & $\begin{array}{c}\text { TLI } \\
>0,90\end{array}$ & $\begin{array}{c}\text { RMSEA } \\
<0,08\end{array}$ \\
\hline Teknostres & 2,271 & 0,902 & 0,908 & 0,938 & 0,906 & 0,919 & 0,073 \\
\hline Dönüşümcü Liderlik & 2,395 & 0,940 & 0,982 & 0,953 & 0,923 & 0,944 & 0,077 \\
\hline Presenteizm & 1,556 & 0,955 & 0,987 & 0,994 & 0,984 & 0,986 & 0,048 \\
\hline İşten Ayrılma Niyeti & 1,029 & 0,997 & 0,998 & 0,999 & 0,998 & 0,991 & 0,021 \\
\hline
\end{tabular}

Uyum iyiliği değerlerinin belirlenmesinde literatürde yaygın kullanılan "kabul edilebilir uyum iyiliği değerleri" esas alınmıştır. Buna göre, teknostres ve dönüşümcü liderlik iyi uyum değerlerine sahip olduğu, presenteizm ve işten ayrılma niyeti ölçeklerinin ise mükemmel uyum değerlerine sahip olduğu görülmüştür (Marsh, Balla ve McDonald, 1988; Hu ve Bentler, 1999; Sivo, Fan, Witta ve Willse, 2006).

Fornell ve Larcker (1981) yapısal modelde anlamlı bir ilişki için test yapmadan önce, ölçüm modelinin yeterli düzeyde geçerlilik ve güvenilirliğe sahip olması gerektiğini belirtmiştir. Bunun için ölçeklerin uyuşum ve ayırt edici geçerliliği sağlaması ve iyi uyum değerlerine sahip olması, ayrıca Cronbach's $\alpha$ değerinin kabul edilebilir sınırlar içerisinde olması beklenmektedir. Ölçeklerin uyuşum geçerliliğini sağlaması için tüm faktör yüklerinin 0,50 eşiğinden fazla olması (Fornell ve Larcker, 1981), maddelerde kendi yapılarıyla çıkarılan ortalama varyansın (AVE) açıklanamayan varyanstan (AVE >0,50) büyük olması (Bagozzi ve Yi, 1988) ve faktör kompozit güvenilirliğinin (CR) 0,60'a eşit veya daha büyük olması gerekmektedir (Fornell ve Larcker, 1981). Fornell ve Larcker (1981), AVE (1) ve CR (2) hesaplanması için aşağıdaki formülleri önermiştir.

$$
\begin{aligned}
& A V E=\frac{\sum_{i=1}^{n} \lambda^{2}}{\mathrm{n}} \\
& C R=\frac{\left(\sum_{i=1}^{i} \lambda_{i}\right)^{2}}{\left(\sum_{i=1}^{i} \lambda_{i}\right)^{2}+\left(\sum_{i=1}^{i} 1-\lambda_{i}^{2}\right)}
\end{aligned}
$$

Öncelikle ölçek maddelerinin faktör yükleri incelenmiştir. 0,50 eşiğinin altında olan teknostres ölçeğindeki aşırı yük boyutunun üçüncü maddesi ve iş güvencesizliği boyutunun ikinci maddesi modelden çıkarılmıştır. Kalan maddelerle yukarıdaki formüllere göre AVE ve CR değerleri Excel 2019 programı ile hesaplanmıştır. Ayrıca değişkenler arası korelasyonlara bakılmıştır. Elde edilen veriler Tablo 3'te ve Tablo 4'te verilmiştir.

\begin{tabular}{|c|c|c|c|c|c|}
\hline Maddeler & $\begin{array}{l}\text { Faktör } \\
\text { Yükü }\end{array}$ & $\alpha$ & CR & AVE & MSV \\
\hline İdealleştirilmiş Etki & & 0,799 & 0,934 & 0,739 & 0,538 \\
\hline IE1 & 0,792 & & & & \\
\hline İE2 & 0,658 & & & & \\
\hline İE3 & 0,731 & & & & \\
\hline İE4 & 0,889 & & & & \\
\hline İE5 & 0,789 & & & & \\
\hline IE6 & 0,858 & & & & \\
\hline IE7 & 0,838 & & & & \\
\hline IE8 & 0,816 & & & & \\
\hline illham Verici Motivasyon & & 0,814 & 0,887 & 0,762 & 0,538 \\
\hline ivM1 & 0,762 & & & & \\
\hline ivM2 & 0,795 & & & & \\
\hline iVM3 & 0,845 & & & & \\
\hline iVM4 & 0,849 & & & & \\
\hline Zihinsel Uyarım & & 0,854 & 0,915 & 0,729 & 0,681 \\
\hline ZU1 & 0,883 & & & & \\
\hline ZU2 & 0,914 & & & & \\
\hline ZU3 & 0,831 & & & & \\
\hline ZU4 & 0,781 & & & & \\
\hline
\end{tabular}

Tablo 3. Ölçek Güvenirlik Analizi Sonuçları 
Tablo 3. Ölçek Güvenirlik Analizi Sonuçları (Devam)

\begin{tabular}{|c|c|c|c|c|c|}
\hline Bireyselleştirilmiş ilgi & & 0,803 & 0,878 & 0,745 & 0,733 \\
\hline Bi1 & 0,826 & & & & \\
\hline Bi2 & 0,747 & & & & \\
\hline віз & 0,753 & & & & \\
\hline Bi4 & 0,878 & & & & \\
\hline Tekno-Aşırı Yük & & 0,712 & 0,836 & 0,707 & 0,577 \\
\hline TEKAY1 & 0,643 & & & & \\
\hline TEKAY2 & 0,775 & & & & \\
\hline TEKAY3 & 0,401 & & & & \\
\hline TEKAY4 & 0,777 & & & & \\
\hline TEKAY5 & 0,734 & & & & \\
\hline TEKAY6 & 0,615 & & & & \\
\hline Tekno-işgal & & 0,744 & 0,786 & 0,754 & 0,577 \\
\hline TEKI1 & 0,746 & & & & \\
\hline TEKI2 & 0,852 & & & & \\
\hline TEKI3 & 0,615 & & & & \\
\hline Tekno-Karmaşıklık & & 0,738 & 0,855 & 0,654 & 0,540 \\
\hline TEKK1 & 0,628 & & & & \\
\hline TEKK2 & 0,803 & & & & \\
\hline TEKK3 & 0,742 & & & & \\
\hline TEKK4 & 0,677 & & & & \\
\hline TEKK5 & 0,820 & & & & \\
\hline Tekno-İş Güvencesizliği & & 0,708 & 0,799 & 0,602 & 0,540 \\
\hline TEKIG1 & 0,729 & & & & \\
\hline TEKIG2 & 0,315 & & & & \\
\hline TEKIG3 & 0,686 & & & & \\
\hline TEKIG4 & 0,803 & & & & \\
\hline TEKIG5 & 0,599 & & & & \\
\hline Tekno-Belirsizlik & & 0,809 & 0,883 & 0,655 & 0,177 \\
\hline TEKB1 & 0,712 & & & & \\
\hline TEKB2 & 0,896 & & & & \\
\hline TEKB3 & 0,874 & & & & \\
\hline TEKB4 & 0,739 & & & & \\
\hline İşten Ayrılma Niyeti & & 0,775 & 0,707 & 0,546 & 0,081 \\
\hline IAN1 & 0,955 & & & & \\
\hline IAN2 & 0,583 & & & & \\
\hline IAN3 & 0,613 & & & & \\
\hline Presenteizm & & 0,817 & 0,857 & 0,668 & 0,046 \\
\hline P1 & 0,746 & & & & \\
\hline $\mathrm{P} 2$ & 0,895 & & & & \\
\hline P3 & 0,803 & & & & \\
\hline P4 & 0,781 & & & & \\
\hline P5 & 0,755 & & & & \\
\hline P6 & 0,753 & & & & \\
\hline
\end{tabular}

Tablo 4. Korelasyon Analizi Bulguları

\begin{tabular}{|c|c|c|c|c|c|c|c|c|c|c|c|c|c|}
\hline & Or. & SS & 1 & 2 & 3 & 4 & 5 & 6 & 7 & 8 & 9 & 10 & 11 \\
\hline 1. IE & 3,50 & 0,97 & - & & & & & & & & & & \\
\hline 2. iVM & 3,45 & 0,98 & $0,92 * * *$ & - & & & & & & & & & \\
\hline 3. ZU & 3,43 & 1,03 & $0,88 * * *$ & $0,86 * * *$ & - & & & & & & & & \\
\hline 4. $\mathrm{BI}$ & 3,19 & 1,05 & $0,86 * * *$ & $0,82^{* * *}$ & $0,83^{* * *}$ & - & & & & & & & \\
\hline 5. TEKA & 3,02 & 0,85 & $0,06^{*}$ & $0,15^{*}$ & $0,17^{*}$ & $0,12^{*}$ & - & & & & & & \\
\hline 6. TEKI & 2,85 & 0,92 & $0,11^{*}$ & $0,16^{*}$ & $0,20 *$ & $0,14^{*}$ & $0,76 * * *$ & - & & & & & \\
\hline 7. TEKK & 2,63 & 0,88 & $0,14 *$ & $0,12^{*}$ & $0,10^{*}$ & $0,09 *$ & $0,36 * * *$ & $0,30 * * *$ & - & & & & \\
\hline 8. TEKIG & 2,49 & 0,83 & $0,10^{*}$ & $0,13^{*}$ & $-0,15^{*}$ & $0,03^{*}$ & $0,42 * * *$ & $0,31 * * *$ & $0,74 * * *$ & - & & & \\
\hline 9. TEKB & 3,20 & 0,89 & $0,23 * *$ & $0,30 * * *$ & $0,28 * * *$ & $0,18^{*}$ & $0,40 * * *$ & $0,42 * * *$ & $0,32 * * *$ & $0,39 * * *$ & - & & \\
\hline 10. IAN & 2,49 & 0,94 & $-0,25 * *$ & $0,16^{*}$ & $-0,17^{*}$ & $-0,27^{*}$ & $0,29 * * *$ & $0,18^{* *}$ & $0,12^{*}$ & $0,16^{*}$ & $0,10 *$ & - & \\
\hline 11. $P R$ & 2,93 & 0,94 & $0,22 * *$ & $0,14^{*}$ & $-0,19 * *$ & $-0,10^{*}$ & $-0,15^{* *}$ & $-0,14 * *$ & $0,13^{*}$ & $-0,09 *$ & $0,18^{*}$ & $0,09 *$ & - \\
\hline \multicolumn{14}{|c|}{ 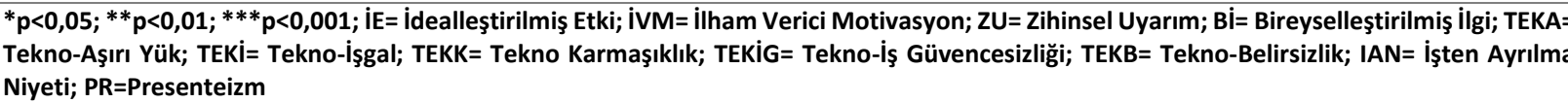 } \\
\hline
\end{tabular}


Yukarıdaki tablolarda verilen sonuçlardan da anlaşılacağı üzere ölçekler yeterli düzeyde uyuşum ve ayırt edici geçerlilik değerlerine sahiptir. Ayrıca tüm ölçeklerin $C R$ ve Alpha değerleri 0,70 'den büyük olduğundan dolayı ölçek güvenirliği de sağlanmıştır. Analizlerde bunun yanı sıra dağılımın normalliğine ve çoklu bağlantı sorunu olup olmadığına bakılmıştır. İlgili analizlerin sonuçları Tablo 5 'te verilmiştir.

Tablo 5. Değişkenlerin Normallik ve Doğrudaşık Analizleri Sonuçları

\begin{tabular}{lcccc}
\hline Değişkenler & Çarpıklık & Basıklık & Tolerans & VIF \\
\hline 1. İdealleştirilmiş Etki & $-0,252$ & $-0,474$ & 0,296 & 3,378 \\
\hline 2. İlham Verici Motivasyon & $-0,248$ & $-0,469$ & 0,261 & 3,835 \\
\hline 3. Zihinsel Uyarım & $-0,372$ & $-0,461$ & 0,259 & 3,865 \\
\hline 4. Bireyselleştirilmiş ilıi & $-0,047$ & $-0,645$ & 0,324 & 3,090 \\
\hline 5. Tekno-Aşırı Yük & 0,483 & $-0,348$ & 0,518 & 1,929 \\
\hline 6. Tekno-Işgal & 0,239 & $-0,325$ & 0,605 & 1,653 \\
\hline 7. Tekno-Karmaşıklık & 0,079 & $-0,396$ & 0,612 & 1,635 \\
\hline 8. Tekno-Iş Güvencesizliği & 0,731 & 0,842 & 0,528 & 1,894 \\
\hline 9. Tekno-Belirsizlik & 0,115 & $-0,077$ & 0,709 & 1,411 \\
\hline 10. İşten Ayrılma Niyeti & 0,404 & $-0,269$ & 0,874 & 1,145 \\
\hline 11. Presenteizm & $-0,111$ & $-0,404$ & 0,938 & 1,066 \\
\hline
\end{tabular}

Kovaryans temelli yapısal eşitlik modellemesi yapabilmek için ön koşullardan biri olarak dağılımın normalliği gösterilmektedir. Normalliği test etmek için ortalaması alınan değişkenlerin çarpıklık ve basıklıkları kontrol edilmiştir. Değerler $+1,5$ ve $-1,5$ sınırını aşmadığı için dağılım normal kabul edilmiştir (Tabachnick, Fidell ve Ullman, 2019). Daha sonra çoklu bağlantı sorunu olup olmadığına bakılmıştır. Değişkenler arasındaki doğrusal regresyon analizi ile elde edilen VIF değerleri literatürde sıkça kabul gören 5 değerinin oldukça altında olduğu için çoklu bağlantı sorunu olmadığı görülmüştür (Craney ve Surles, 2002). Bu sonuçlarla ölçeklerin yapı geçerliliği, güvenilirliği ve ön koşulların sağladığı görülmüştür ve yapısal model analizlerine geçilmiştir.

\subsection{Yapısal Model Analizi}

Oluşturulan hipotezleri test etmek için analizin ikinci adımında yapısal model kurulmuştur. Aracı etkilerin de test edildiği bu modelde aracılık etkisini test etmek için Baron ve Kenny (1986) tarafından önerilen adımlar izlenmiştir. Analiz yöntemi olarak, kitle parametresine ilişkin güven aralığının hesaplanmasına olanak sağlayan, bootstrap yöntemi kullanılmıştır. Bootstrap örneklemi ise 2000 olarak belirlenmiştir. Doğrudan ve dolaylı etkileri test etmek için kurulan modelin uyum iyiliği değerlerinin $\chi^{2} / \mathrm{df}=3,267, \mathrm{RMSEA}=0,076, \mathrm{NFI}=$ $0,977, \mathrm{TLI}=0,986, \mathrm{CFI}=0,982, \mathrm{GFI}=0,991$ kabul edilebilir sınırlar içinde olduğu görülmüştür. Kurulan modeldeki doğrudan etki sonuçları Tablo 6 'da verilmiştir.

Tablo 6'da görüldüğü üzere tekno karmaşıklığın dönüşümcü liderliği algılama üzerinde pozitif yönlü ve anlamlı $(\beta=0,159)$ bir etkisi vardır. Tekno iş güvencesizliğinin dönüşümcü liderlik üzerinde negatif yönlü ve anlamlı $(\beta=-0,198)$, presenteizm üzerinde ise pozitif yönlü ve anlamlı $(\beta=, 256)$ bir etkiye sahip olduğu görülmektedir. Tekno belirsizliğin dönüşümcü lideri algılaması üzerinde negatif yönlü ve anlamlı $(\beta=-0,266)$ bir etkisi vardır. Tekno aşırı yük $(\beta=0,248)$ ve tekno iş güvencesizliğinin $(\beta=0,256)$ presenteizm üzerinde pozitif yönlü ve anlamlı bir etkisi olduğu tespit edilmiştir. Ayrıca dönüşümcü liderliğin işten ayrılma niyetini $(\beta=-0,241)$ ve presenteizm davranışını $(\beta=-0,167)$ azalttığı bulgulanmıştır. Araştırmanın bulgularına göre " $H_{1}$ : Teknostres presenteizm davranışını etkilemektedir" hipotezi tekno aşırı yük, tekno karmaşıklık, tekno iş güvencesizliği boyutları için kabul edilirken; tekno işgal ve tekno belirsizlik boyutları için reddedilmiştir. Ayrıca " $\mathrm{H}_{2}$ : Teknostres işten ayrılma niyetini etkilemektedir" hipotezi tüm alt boyutlar için reddedilmiştir. Çalışmanın bağımsız değişkeni ile aracı değişkeni arasındaki ilişkiyi test etmek üzere kurulan " $\mathrm{H}_{3}$ : Teknostres dönüşümcü liderlik algısını etkilemektedir" hipotezi teknostresin tekno karmaşıklık, tekno iş güvencesizliği ve tekno belirsizlik boyutları için kabul edilirken; tekno aşırı yük ve tekno işgal boyutları için reddedilmiştir. Dönüşümcü liderliğin bağımlı değişkenler olan işten ayrılma niyeti ve presenteizm üzerindeki etkisini ölçmeye yönelik 
kurulan " $\boldsymbol{H}_{4}$ : Dönüşümcü liderlik presenteizm davranışını etkilemektedir" ve " $\boldsymbol{H}_{5}$ : Dönüşümcü liderlik işten ayrılma niyetini etkilemektedir" hipotezleri ise kabul edilmiştir.

Tablo 6. Doğrudan Etki Analizi Sonuçları

\begin{tabular}{|c|c|c|c|c|c|c|}
\hline & & & Katsayı & S.H. & к.O. & p \\
\hline Dönüşümcü Liderlik & $<--$ & Tekno Aşırı Yük & $-0,008$ & 0,090 & $-0,087$ & 0,930 \\
\hline Dönüşümcü Liderlik & $<--$ & Tekno İşgal & 0,039 & 0,078 & 0,497 & 0,620 \\
\hline Dönüşümcü Liderlik & $<--$ & Tekno Karmaşıklık & 0,159 & 0,082 & 1,935 & 0,048 \\
\hline Dönüşümcü Liderlik & $<--$ & Tekno İş Güvencesizliği & $-0,198$ & 0,093 & $-2,125$ & 0,034 \\
\hline Dönüşümcü Liderlik & $<--$ & Tekno Belirsizlik & $-0,266$ & 0,073 & 3,642 & 0,000 \\
\hline İşten Ayrılma Niyeti & $<--$ & Tekno Aşırı Yük & 0,138 & 0,091 & 1,516 & 0,129 \\
\hline Presenteizm & $<--$ & Tekno Aşırı Yük & 0,248 & 0,092 & $-2,682$ & 0,007 \\
\hline İşten Ayrılma Niyeti & $<--$ & Tekno İşgal & 0,099 & 0,079 & 1,253 & 0,210 \\
\hline Presenteizm & $<--$ & Tekno İşgal & 0,098 & 0,078 & 1,246 & 0,213 \\
\hline İşten Ayrılma Niyeti & $<--$ & Tekno Karmaşıklık & $-0,070$ & 0,083 & $-0,843$ & 0,399 \\
\hline Presenteizm & $<--$ & Tekno Karmaşıklık & 0,270 & 0,083 & 3,270 & 0,001 \\
\hline İşten Ayrılma Niyeti & $<--$ & Tekno İş Güvencesizliği & 0,085 & 0,095 & 0,902 & 0,367 \\
\hline Presenteizm & $<--$ & Tekno İş Güvencesizliği & 0,256 & 0,094 & $-2,728$ & 0,006 \\
\hline İşten Ayrılma Niyeti & $<--$ & Tekno Belirsizlik & 0,132 & 0,075 & $-1,754$ & 0,079 \\
\hline Presenteizm & $<--$ & Tekno Belirsizlik & 0,123 & 0,075 & $-1,642$ & 0,101 \\
\hline İşten Ayrılma Niyeti & $<---$ & Dönüşümcü Liderlik & $-0,241$ & 0,065 & $-3,679$ & 0,000 \\
\hline Presenteizm & $<--$ & Dönüşümcü Liderlik &,- 167 & ,065 & $-2,570$ & 0,010 \\
\hline
\end{tabular}

Araştırmanın $\mathrm{H}_{6}$ ve $\mathrm{H}_{7}$ hipotezleri dönüşümcü liderliğin teknostres ile presenteizm davranışı ve işten ayrılma niyeti arasındaki ilişkide aracı bir rol üstlenebileceğini öngörmektedir. Baron ve Kenny (1986) yaptıkları çalışmada aracı değişkeni; bağımsız değişken ile bağımlı değişken arasındaki etkinin üretkenliği şeklinde tanımlamıştır. Ayrıca aracılık etkisi üç koşula bağlanmıştır. Buna göre, birinci koşul bağımsız değişkenin bağımlı değişkeni etkilemesi, ikinci koşul bağımsız değişkenin aracı değişkenler üzerinde bir etkisinin olması, üçüncü koşul aracı değişkenin bağımlı değişkeni etkilemesidir. Yazarlar, tüm bu koşulların sağlanması durumunda; aracı etki modele girdiği takdirde bağımlı değişken ile bağımsız değişken arasındaki ilişki azalıyorsa kısmi, bağımlı değişken ile bağımsız değişken arasındaki ilişki anlamsızlaşıyorsa tam aracılığın olduğunu savunmuşlardır. Aracılık etkisini test etmek için Baron ve Kenny (1986) tarafından önerilen adımlar izlenmiştir. Böylece doğrudan etkileri test etmek için kurulan modeldeki anlamlı yollarla yeni bir model kurulmuştur. Kurulan bu modelin uyum iyiliği değerleri $\chi^{2} / d f=2,815, \operatorname{RMSEA}=0,069, \mathrm{NFI}=0,987, T L I=0,996$, $\mathrm{CFI}=0,988, \mathrm{GFI}=0,997$ olarak ölçülmüştür. Analiz yöntemi olarak kitle parametresine ilişkin güven aralığının hesaplanmasına olanak sağlayan bootstrap yöntemi kullanılmıştır. Bootstrap örneklemi ise 5000 olarak belirlenmiştir. Bu aracılık ilişkisini test etmek üzere oluşturulan modelin bulguları Tablo 7'de paylaşılmıştır.

Tablo 7. Dolaylı Etki Analizi Sonuçları

\begin{tabular}{|c|c|c|c|c|}
\hline & $\begin{array}{c}\text { Doğrudan } \\
\text { Etki }^{1} \\
\beta\end{array}$ & $\begin{array}{c}\text { Doğrudan } \\
\text { Etki² }^{2} \\
\beta\end{array}$ & $\begin{array}{c}\text { Dolaylı } \\
\text { Etki } \\
\beta\end{array}$ & Aracılık Durumu \\
\hline Tekno Belirsizlik $\rightarrow$ Dönüşümcü Liderlik $\rightarrow$ Presenteizm & $0,159 * *$ & $0,058(n s)^{3}$ & $0,179 * * *$ & Tam Aracılık \\
\hline $\begin{array}{l}\text { Tekno İ̧̧ Güvencesizliği } \rightarrow \text { Dönüşümcü Liderlik } \rightarrow \\
\text { Presenteizm }\end{array}$ & $0,198 * *$ & $0,112^{*}$ & $0,098^{*}$ & Kısmi Aracılık \\
\hline $\begin{array}{l}\text { Tekno Karmaşıklık } \rightarrow \text { Dönüşümcü Liderlik } \rightarrow \\
\text { Presenteizm }\end{array}$ & $0,230 * * *$ & $0,056(n s)^{3}$ & $0,189 * * *$ & Tam Aracılık \\
\hline
\end{tabular}

Yapılan aracı model analizi sonuçlarına göre dönüşümcü liderlik, tekno belirsizlik ve tekno karmaşıklık ile presenteizm arasındaki ilişkiye tam aracılık ederken; tekno iş güvencesizliği ile presenteizm davranışı arasındaki ilişkiye kısmi aracılık etmektedir. Buna göre " $\mathrm{H}_{6}$ : Dönüşümcü liderlik teknostres ile presenteizm 
davranışı arasındaki ilişkide aracı etkiye sahiptir" hipotezi kabul edilmiştir. Ayrıca teknostres ile işten ayrılma niyeti arasında anlamlı bir ilişki bulunmadığından " $\mathrm{H}_{7}$ : Dönüşümcü liderlik teknostres ile işten ayrılma niyeti arasındaki ilişkide aracı etkiye sahiptir" hipotezi reddedilmiştir.

\section{Tartışma ve Sonuç}

Günümüzde teknolojiyle bağı olmayan kişi veya örgüt yok denecek kadar azdır. Teknolojinin yaygın kullanımının pek çok faydasına rağmen belirli bir noktada örgütler için problem kaynağı olduğu bilinmektedir. Teknolojinin doğası gereği ona hızlı bir şekilde uyum sağlamak ve iş yapma biçimlerini bazen kökünden değiştirmek gerekmektedir. Bu durum, bazı çalışanlarda endişe ve kaygıya neden olarak bireysel ve örgütsel verimliliği etkilemektedir. Teknostres adı verilen bu kavram araştırmanın temel amacı olmuştur. Özele inildiğinde ise teknostresin presenteizm ve işten ayrılma niyetine etkisi ile dönüşümcü liderliğin bu süreçteki aracı rolü araştırılmıştır.

Araştırma sonucunda teknostresin boyutlarından tekno-aşırı yük, tekno-karmaşıklık ve tekno-iş güvencesizliğinin presenteizme etki ettiği; fakat tekno - işgal ve tekno - belirsizlik boyutlarının presenteizme etki etmediği tespit edilmiştir. Elde edilen sonuçlar Ayyagari vd.'nin (2011) “teknostres ile presenteizm arasında ilişki vardır" bulgusuyla örtüşmektedir.

Araştırma bulgularına göre teknostresin işten ayrılma niyetine etki etmediği tespit edilmiştir. Elde edilen sonuçlar Tu vd.'nin (2005) çalışmalarında kanıtlanan ilişkiyle ayrışmaktadır. Araştırma sonucunda teknostresin boyutlarından tekno karmaşıklık, tekno iş güvencesizliği ve tekno belirsizliğin dönüşümcü liderlik algısını etkilediği; fakat tekno aşırı yük ve tekno işgal boyutlarının dönüşümcü liderliği etkilemediği tespit edilmiştir. Elde edilen sonuçlar Boyer-Davis'in (2018) teknostresin dönüşümcü liderlikle ilişkisi yoktur bulgusuyla paralellik göstermektedir.

Çalışmanın bulgularına göre dönüşümcü liderliğin presenteizmi etkilediği tespit edilmiştir. Elde edilen sonuçlar Nielsen ve Daniels'ın (2016) çalışmalarıyla aynı çıkmışır. Ayrıca araştırma sonucunda dönüşümcü liderliğin işten ayrılma niyetini etkilediği tespit edilmiştir. Bu sonuçlar Tekingündüz ve Kurtuldu'nun (2015) dönüşümcü liderlik ile işten ayrılma niyeti arasında ilişki yoktur bulgusundan farklılaşmaktadır. Son olarak, yapılan analizlerde teknostres ile presenteizm arasında dönüşümcü liderliğin aracı rol oynadığı tespit edilmiştir.

Sonuç olarak, teknostresin iş yerinde var olamama üzerinde önemli bir etkiye sahip olduğu görülmüştür. Stresin bu tip etkileri aslına beklenen bir durumdur. Buna karşın yaşanan teknostresin bireyleri işten ayrılmaya itecek kadar ileri düzeyde olmadığı tespit edilmiştir. Buna göre, günümüzde yaşanan teknolojik gelişmelerin hayatın her alanına sirayet etmesinden ötürü çalışanların işten ayrılmayı bir seçenek olarak görmedikleri savunulabilir. Başka bir deyişle bulabilecekleri benzer işlerde de yaşanacak olan teknostres öncekinden farklı olmayacaktır.

Araştırmanın diğer çarpıcı bulgusu, bireyin yaşadığı teknostresin presenteizm davranışına etkisinde dönüşümcü lider algısının aracılık edebileceğidir. Lider, doğası gereği organizasyonun önemli işleyişlerine etki edebilecek konumdadır. Çalışanların hayatlarına çok önemli dokunuşlar yapmak da liderliğin ve özelde dönüşümcü liderliğin bir özelliğidir. Bu çalışmanın bulgularıyla da liderin önemi bir kez daha kanıtlanmıştır. Böylece dönüşümcü liderin, yaşanan stresin etkilerini azaltarak çalışanların iş ve yaşam kalitelerine etki ettiği gözler önüne serilmiştir.

Çalışmada elde edilen bulgulara göre örgüt yöneticilerine ve diğer paydaşlara birtakım tavsiyelerde bulunulmuştur. Buna göre:

- Örgütün dış çevreye uyum sağlaması ancak atılan adımların sağlıklı olmasına bağlıdır. Bu nedenle, çalışanlara yeteneklerine uygun görevler verilmeli ve onların yeni düzene uyum sağlamaları için gerekli imkânlar sağlanmalıdır. 
- Teknostres ve presenteizm sonucu ortaya çıkan işten ayrılmaların örgütlere maliyeti oldukça yüksektir. Buna göre çalışanlar işten çıkmadan veya çıkarılmadan önce yetişmiş elemanlardan istifade etmenin alternatifleri araştırılmalıdır.

- Örgütlerde liderler belirleyici rol üstlenmektedir. Dönüşümcü liderlerin örgüte vereceği yön son derece kritik olduğu için liderlere fırsatlar tanınmalı ve organizasyonu dönüştürebilecek ortamlar sunulmalıdır.

- Presenteizmin bir tür kaçak olduğu düşünülerek onun oluşmasına zemin hazırlayan etmenler ortadan kaldırımalı, çalışanlarla etkili iletişim kurulmalı ve örgütün kaynaklarını doğru kullanmanın önü açılmalıdır.

Son olarak çalışmanın bazı kısıtlılıkları olduğunu ve bu kısıtlııkların aynı zamanda gelecek çalışmalar için fırsatlar sunabileceğini belirtmek gerekir. Çalışmanın saha araştırmasının zaman ve maliyet etkenleri nedeniyle sadece Malatya ilinde gerçekleştirilmiş olması bir kısıtlııktır. Diğer kıııtlılık ise sadece gönüllü olan katılımcılardan elde edilen verilerin analizlerde işlenmesidir. Bu durum örneklem sayısının genellenebilirlik açısından zayıf olmasına neden olmuştur. Gelecek çalışmalara bu durumu göz önünde bulundurarak araştırmaların daha geniş örneklem grubunda, daha çok sayıda katılımcıyla ve daha farklı coğrafyalarda yapılması önerilmektedir. Ayrıca, farklı liderlik tiplerinin de teknostres ile işten ayrılma niyeti ve presenteizm davranışı arasında aracı rol üstlenebileceği düşünülmektedir. Bu bağlamda gelecek çalışmalara paternalistik liderlik tipi ile ilham verici liderliğin aracılık rolünü irdelemeleri tavsiye edilmektedir. Son olarak teknostresin tükenmişlik ile de ilişkili olabileceği düşünülmektedir. Bağımlı değişken olarak tükenmişliğin incelenmesi ilgili literatüre müspet katkılar sunabilecektir.

\section{Beyan ve Açıklamalar (Disclosure Statements)}

1. Bu çalışmanın yazarları, araştırma ve yayın etiği ilkelerine uyduklarını kabul etmektedirler (The authors of this article are admitted that they complied with the principles of research and publication ethics).

2. Yazarlar tarafından herhangi bir çıkar çatışması beyan edilmemiştir (No potential conflict of interest was reported by the authors).

3. Bu çalışma, intihal tarama programı kullanılarak intihal taramasından geçirilmiştir (This article was screened for potential plagiarism using a plagiarism screening program).

\section{Kaynaklar}

Akınoğlu, H. F. G. (1993). Teknostres. Türk Kütüphaneciliği, 7(3), 159-173

American Institute of Stress, (2007). Job stress. http://www.stress.org/job.htm (Erişim Tarihi: 13.12.2019)

Anderson, J. C., \& Gerbing, D. W. (1988). Structural equation modeling in practice: A review and recommended twostep approach. Psychological Bulletin, 103(3), 411-423.

Ariyabuddhiphongs, V., \& Kahn, S. I. (2017). Transformational leadership and turnover intention: The mediating effects of trust and job performance on café employees in Thailand. Journal of Human Resources in Hospitality \& Tourism, 16(2), 215-233.

Attar, M. (2014). Üst düzey yöneticilerin liderlik özelliklerinin örgütsel ustalık düzeyine etkisi: Türk bankacılık sektörü üzerine bir araştırma. Selçuk Üniversitesi Sosyal Bilimler Enstitüsü, Yayınlanmamı̧ Doktora Tezi, Konya.

Ayyagari, R., Varun, G., \& Russell, P. (2011). Technostress: Technological antecedents and implications. Management Information Systems, 35(4), 831-859.

Bagozzi, R. P., \& Yi, Y. (1988). On the evaluation of structural equation models. Journal of the Academy of Marketing Science, 16(1), 74-94. 
Baron, R. M., \& Kenny, D. A. (1986). The moderator-mediator variable distinction in social psychological research: Conceptual, strategic, and statistical considerations. Journal of Personality and Social Psychology, 51(6), 11731182.

Bartlett, K. R. (1999). The relationship between training and organizational commitment in the health care field. The University of Illinois, Yayınlanmamış Doktora Tezi, Chicago, USA.

Bass, B. M. (1997). Does the transactional-transformational leadership paradigm transcend organizational and national boundaries? American Psychologist, 52(2), 130-139.

Bass, B. M., \& Avolio, B. J. (1994). Transformational leadership and organizational culture. The International Journal of Public Administration, 17(3), 541-554.

Bayar, A. (2016). Eğitim kurumlarında presenteizm'in azaltılmasında ödüllendirmenin rolü. Bahçeşehir Üniversitesi, Yayımlanmış Yüksek Lisans Tezi, İstanbul.

Bayarçelik, E. B., \& Fındıklı, M. (2017). İş tatminin, örgütsel adalet ve işten ayrılma niyeti ilişkisindeki aracılık rolü. Beykent Üniversitesi Sosyal Bilimler Dergisi, 10(1), 16-31.

Boyer-Davis, S. (2018). The relationship between technology stress and leadership style: An empirical investigation. Journal of Business and Educational Leadership, 8(1), 48-65.

Boyer-Davis, S. (2019). The empirical relationship between leadership style and technostress. ASBBS Proceedings, 26, 99-112.

Brillhart, P. E. (2004). Technostress in the workplace: Managing stress in the electronic workplace. Journal of American Academy of Business, 5(1/2), 302-307.

Cammann, C., Fichman, M., Jenkins, G. D., \& Klesh, J. (1983). Michigan organizational assessment questionnaire. In S. E. Seashore, E.E. Lawler, P. H. Mirvis, \& C. Cammann (Ed.), Assessing organizational change: A guide to methods, measures, and practices, New York: Wiley-Interscience, 71-138.

Champion, S. (1988) Technostress technology's toll. School Library Journal, 35, 48-51.

Clark, K., \& Kalin, S. (1996). Technostressed out? How to cope in the digital age. Library Journal, 121(13), 30-32.

Cooper, C. L., \& Williams, S. (1994). Creating healthy work organizations. San Francisco: John Wiley \& Sons.

Coşkun, Ö. (2012). Iki işyerinde işe devamsızlık ve kendini işe verememede etkili faktörlerin değerlendirilmesi. Ankara Üniversitesi Sağlık Bilimleri Enstitüsü, Yayımlanmamış Yüksek Lisans Tezi, Ankara.

Craney, T. A., \& Surles, J. G. (2002). Model-dependent variance inflation factor cutoff values. Quality Engineering, 14(3), 391-403.

Cullen, J., \& McLaughlin, A. (2006). What drives the persistence of presenteeism as a managerial value inhotels?: Observations noted during an Irish work-life balance research project, International Journal of Hospitality Management, 25(3), 510-516.

Çetin, D., \& Bülbül, T. (2017). Okul yöneticilerinin teknostres algıları ile bireysel yenilikçilik özellikleri arasındaki ilişkinin incelenmesi. Abant İzzet Baysal Üniversitesi Eğitim Fakültesi Dergisi, 17(3), 1241-1264.

Çetin, D. (2017). Okul yöneticilerinin teknostres algıları ile bireysel yenilikçilik özellikleri arasındaki ilişkinin incelenmesi (Edirne ili örneği). Trakya Üniversitesi Sosyal Bilimler Enstitüsü, Yayımlanmamış Yüksek Lisans Tezi, Edirne.

Çiçek, B., \& Aknar, A. (2019). Kişilik özelliklerinin tükenmişlik ve presenteizm davranışları üzerindeki etkisi. Üçüncü Sektör Sosyal Ekonomi Dergisi, 54(3), 1234-1258.

Çiftçi, B. (2010). İşte var ol(ama)ma sorunu ve işletmelerin uygulayabileceği çözüm önerileri. Çalışma ve Toplum Dergisi, $1(1), 153-174$.

D'abate, C. P., \& Eddy, E. R. (2007). Engaging in personal business on-the-job: Extending the presenteeism construct. Human Resource Development Quarterly, 18(3), 361-383.

Erkorkmaz, Ü., Etikan, İ., Demir, O., Özdamar, K., \& Sanisoğlu, S. Y. (2013). Doğrulayıcı faktör analizi ve uyum indeksleri. Türkiye Klinikleri Journal of Medical Sciences, 33(1), 210-223.

Ferreira, A. I., \& Martinez, L. F. (2012). Presenteeism and burnout among teachers in public and private portuguese elementary schools. The International Journal of Human Resource Management, 23(20), 4380-4390.

Fieseler, C., Grubenmann, S., Meckel, M., \& Müller, S. (2014, January). The leadership dimension of coping with technostress. 47th Hawaii International Conference on System Sciences, IEEE, 530-539.

Fornell, C., \& Larcker, D. F. (1981). Evaluating structural equation models with unobservable variables and measurement error. Journal of Marketing Research, 18(1), 39-50. 
Fried, Y., Shirom, A., Gilboa, S., \& Cooper, C. L. (2008). The mediating effects of job satisfaction and propensity to leave on role stress-job performance relationships: Combining meta-analysis and structural equation modeling. International Journal of Stress Management, 15(4), 305-328.

George, R., Chiba, M., \& Scheepers, C. B. (2017). An investigation into the effect of leadership style on stress-related presenteeism in South African knowledge workers. SA Journal of Human Resource Management, 15(1), 1-13.

Gül, H. (2003). Bilgi toplumu karizmatik liderliğin sonu olur mu? http://www.bilgiyonetimi.org/cm/pages/mkl_gos.php (Erişim Tarihi: 04.12.2019).

Hang-Yue, N., Foley, S., \& Loi, I. R. (2005). Work role stressors and turnover intentions: A study of professional clergy in Hong Kong. International Journal of Human Resource Management, 16(11), 2133-2146.

Harman, H. H. (1967). Modern factor analysis. Chicago: University of Chicago Press.

Hemp, P. (2004). Presenteeism: At work-but out of it. Harvard Business Review, 82(10), 49-58.

Hu, L. T., \& Bentler, P. M. (1999). Cutoff criteria for fit indexes in covariance structure analysis: Conventional criteria versus new alternatives. Structural Equation Modeling: A Multidisciplinary Journal, 6(1), 1-55.

Hung, W. H., Chang, L. M., \& Lin, C. H. (2011). Managing the risk of overusing mobile phones in the working environment: A study of ubiquitous technostress. In: Proc 15th pacific Asia conference on information systems, Brisbane, 1-12.

lacobucci, D., Saldanha, N., \& Deng, X. (2007). A meditation on mediation: Evidence that structural equations models perform better than regressions. Journal of Consumer Psychology, 17(2), 139-153.

Ilgaz, G., Özgür, H., \& Çuhadar, C. (2016). The adaptation of technostress scale into Turkish. Abstracts of the 11th International Balkan Education and Science Congress, (p. 6) Poreč, Croatia.

Isetti, D., \& Meyer, T. (2014). Workplace productivity and voice disorders: A cognitive interviewing study on presenteeism in individuals with spasmodic dysphonia. Journal of Voice, 28(6), 700-710.

Issa, H., \& Bahli, B. (2018). Understanding the consequences of technostress: A non-linear perspective. In ECIS (p. 71).

İşçan, Ö. F., \& Moç, T. (2018). Çalışanların presenteizm (işte sözde var olma) davranışlarının işe yabancılaşmalarına etkisi: Bir kamu kurumu örneği. İşletme Araştırmaları Dergisi, 10(3), 379-402

Kahn, J. H. (2006). Factor analysis in counseling psychology research, training, and practice: Principles, advances, and applications. The Counseling Psychologist, 34(5), 684-718.

Kaya, E. (2010). İş stresi ve tükenmişlik duygusunun işten ayrılma niyeti üzerine etkileri: Sağlık personeli üzerinde bir uygulama. Gebze Teknik Üniversitesi Sosyal Bilimler Enstitüsü, Yayımlanmamış Yüksek Lisans Tezi, Kocaeli.

Khan, I., Nawaz, A., Khan, F., Khan, H., \& Yar, N. B. (2013). Determining the impact of demographics on the intention to leave of academicians in HEls of the DCs like Pakistan. Global Journal of Management and Business Research Administration and Management, 13(7), 40-48.

Kılınç, E. (2019). Stratejik ve dönüşümcü liderlik ile işgören performansı ilişkisi: Sağılık sektöründe bir araştırma. İnönü Üniversitesi Sosyal Bilimler Enstitüsü, Yayımlanmamış Doktora Tezi, Malatya.

Kline, R. B. (2005). Principles and practice of structural equation modeling. New York: Guilford Press.

Knani, M. (2013). Exploratory study of the impacts of new technology implementation on burnout and presenteeism. International Journal of Business and Management, 8(22), 92.

Koopman, C., Pelletier, K. R., Murray, J. F., Sharda, C. E., Berger M. L., Turpin R., Hackleman, P., Gibson, P., Holmes D. M., \& Bendel T. (2002). Stanford presenteeism scale: Health status and employee productivity. Journal of Occupational Environmental Medicine, 44, 14-20.

Larjovuori, R. L., Bordi, L., Mäkiniemi, J. P., \& Heikkilä-Tammi, K. (2016). The role of leadership and employee well-being in organizational digitalization. Tiziana Russo-Spenaand Cristina Mele, 1141-1154.

Laspinas, M. L. (2015). Technostress: Trends and challenges in the 21st century knowledge management. European Scientific Journal, 11(2), 205-217.

Lee, Y. K., Chang, C. T., Lin, Y., \& Cheng, Z. H. (2014). The dark side of smartphone usage: Psychological traits, compulsive behavior and technostress. Computers in Human Behavior, 31, 373-383.

Lowe, G. (2004) Here in body, absent in productivity - presenteeism hurts! http://www.refresher.com/!gslpresenteeism.html (Erişim Tarihi: 25.12.2019).

Marsh, H. W., Balla, J. R., \& McDonald, R. P. (1988). Goodness-of-fit indexes in confirmatory factor analysis: The effect of sample size. Psychological Bulletin, 103(3), 1-25.

Martens, M. P. (2005). The use of structural equation modeling in counseling psychology research. The Counseling Psychologist, 33(3), 269-298. 
Muthén, L. K., \& Muthén, B. (2017). Mplus user's guide: Statistical analysis with latent variables, user's guide.

Nielsen, K., \& Daniels, K. (2016). The relationship between transformational leadership and follower sickness absence: The role of presenteeism. Work and Stress, 30(2), 193-208.

Podsakoff, P. M., MacKenzie, S. B., Lee, J. Y., \& Podsakoff, N. P. (2003). Common method biases in behavioral research: A critical review of the literature and recommended remedies. Journal of Applied Psychology, 88(5), 879-903.

Quintana, S. M., \& Maxwell, S. E. (1999). Implications of recent developments in structural equation modeling for counseling psychology. The Counseling Psychologist, 27(4), 485-527.

Ragu-Nathan, T. S., Tarafdar, M., Ragu-Nathan, B. S., \& Tu, Q. (2008). The consequences of technostress for end users in organizations: Conceptual development and empirical validation. Information Systems Research, 19(4), 417433.

Riedl, R., Kindermann, H., Auinger, A., \& Javor, A. (2012). Technostress from a neurobiological perspective. Business \& Information Systems Engineering, 4(2), 61-69.

Saarvala, E. (2006). Presenteeism: The latest attack on economic and human productivity. Human Resources Management, 1, 1-10.

Samuel, R. J., \& Wilson, L. M. (2007). Is presenteeism hurting your workforce?. Employee Benefit Plan Review, 61(11), 5.

Sanderson, P. A. (2003). The relationships between empowerment and turnover intentions in a structured environment: An assessment of the navy's medical service corps. Regent University, School of Leadership Studies.

Schreiber, J. B., Nora, A., Stage, F. K., Barlow, E. A., \& King, J. (2006). Reporting structural equation modeling and confirmatory factor analysis results: A review. The Journal of Educational Research, 99(6), 323-338.

Sivo, S. A., Fan, X., Witta, E. L., \& Willse, J. T. (2006). The search for" optimal" cutoff properties: Fit index criteria in structural equation modeling. The Journal of Experimental Education, 74(3), 267-288.

Tabachnick, B. G., Fidell, L. S., \& Ullman, J. B. (2019). Using multivariate statistics. Boston, MA: Pearson.

Tarafdar, M., Ragu-Nathan, T. S., Ragu-Nathan, B., \& Tu, Q. (2007). The impact of technostress on productivity. Journal of Management Information Systems, 24(1), 301-328.

Tekingündüz, S., \& Kurtuldu, A. (2015). İşten ayrılma niyeti, iş tatmini, örgütsel bağlılık, liderlik ve iş stresi arasındaki ilişkilerin analizi: Bir hastane örneği. International Journal of Human Sciences, 12(1), 1501- 1517.

Tekingündüz, S., Top, M., \& Seçkin, M. (2015). İş tatmini, performans, iş stresi ve işten ayrılma niyeti arasındaki ilişkilerin incelenmesi: Hastane örneği. Verimlilik Dergisi, 1(4), 39-64

Tu, Q., Wang, K., \& Shu, Q. (2005). Computer-related technostress in China. Communication of the ACM, 48(4), 77-81.

Weston, R., \& Gore Jr., P. A. (2006). SEM 101: A brief guide to structural equation modeling. The Counseling Psychologist, 34, 719-751.

Williams, J., \& MacKinnon, D. P. (2008). Resampling and distribution of the product methods for testing indirect effects in complex models. Structural Equation Modeling: A Multidisciplinary Journal, 15(1), 23-51. 